\title{
NON SPIROGRAPHIC OR NONINVASIVE METHODS TO ESTIMATE ANAEROBIC TRESHOLD
}

\author{
Raúl Josué Nájera-Longoria ${ }^{1}$, Omar Ricardo Ortiz Gomez ${ }^{1}$, Jesús Salvador López Alonso ${ }^{1}$, \\ Ramón Candia-Lujan ${ }^{1}$, Oscar Nuňez Enriquez ${ }^{2}$, Roberto Gutierrez Martinez ${ }^{1}$, Željko M. Rajkovićs \\ ${ }^{1}$ Autonomous University of Chihuahua, Faculty of Physical Culture Sciences, Mexico \\ ${ }^{2}$ New Mexico State University, USA \\ ${ }^{3}$ University of Belgrade, Faculty of Sport and Physical Education, Serbia
}

\begin{abstract}
In the world of sports research, there are different ways to determinate physical conditioning, ranging from expensive laboratory-invasive methods to cheap, field based-non-invasive methods. The field based-non-invasive test maintains good reliability and low cost using physiological parameters such heart rate, saliva electrolytes or lactate, perceived exertion and electromyography among others. These parameters can be used to estimate anaerobic threshold (AnT) to predict sport performance, redirect training and can help coaches and athletes to be more competitive. However, each of this parameter has some particularities and controversy due to different results reported by specialist. These differences may be explained by protocol testing used, sport level sample, starting intensity or number of levels among others. Despite this, they still have good reproducibility and applications on field based test protocols. Mentioned tests could be used in a large scale, and more often, with paying attention about level of correlation with original invasive tests, and percent of possible mistake in estimation process. Cheaper, and simpler tests (instead subjective estimation of training load) allows using more precise planning and changing volume, and intensity of training, for coaches, and athletes, that have needed level of education and less money. Athletes comfort, and possible high frequency of testing during non invasive test, also must be emphasized as an advantage during training evaluation process.
\end{abstract}

Key Words: HART RATE / SALIVA / PERCEIVED EXERTION / ELECTROMYOGRAPHY / BLOOD LACTATE / ERGOMETRY

\section{INTRODUCTION}

At least fifty years have passed since Wasserman and Mcllory (1964) developed the anaerobic threshold concept (AnT) which is defined as the lost between ventilator elements and workload within oxygen consumption and coincides with the upper limit of individual aerobic metabolism, besides this parameter relates to prolonged exercise performance (Davis, 1985; Ignjatović, Hofmann, \& Radovanović, 2008; Wasserman \& McIlroy, 1964).

There is no doubt about the importance of the determination of the AnT, however, there is still controversy surrounding the different forms to determinate de AnT. There are unnumbered methods to estimate ranging from invasive (blood lactate) or uncomfortable and expensive (spirographic, electromyograph- ic, magnetic resonance) and non-invasive methods (Bodner \& Rhodes, 2000; Lopez-Chicharro, Calvo, Alvarez, Vaquero, Bandres, \& Legido, 1995; de Assis, Piubelli, Mello, Pereira, Guerra, \& Silva, 2015). In this subgroup are the determination of AnT through saliva, perceived exertion, deflection of the heart rate, talk test among others and which they maintain good reliability and at low cost.

The purpose of this review paper is to present the different non-spirographic and non-invasive methods that determine AnT. A research of different databases including EBSCO, Spordiscus specifically looking for "anaerobic threshold", "lactate threshold" and "ventilatory threshold" as was made. 


\section{METHOD}

In this article bibliographical, historical and causal methods were used, with logical, deductive and inductive way of conclusion. Beside systematization of personal professional experience in practical determination of AnT, method of Theory analysis was used also.

\section{RESULTS AND DISCUSSION}

Most important characteristic of anaerobic threshold is that lactates in blood, after critical point shows sudden increase, which in a milder form leads to deterioration of concentration and co-ordination, and in extreme cases, to stopping of all activities (Damnjanović, 2016). Defining anaerobic threshold for specific athlete is a determining fact for the dosage of training, mainly in sports in which endurance is dominant component (rowing, canoeing, running, cycling, swimming etc.), (Grujić at all, 2017), but also in other sports in specific phase of preparation. On behalf of different parameters which were recorded on AnT level, specific "derived" AnT could be defined, such as speed of the boat during AnT, or stroke frequency during AnT, during specific time or length section in rowing, for each rower. (Ilić \& Rajković, 2009).

There are many different methods of defining anaerobic threshold. In order for defining a useful method, it should be conductive, and should assess the width of the threshold with certain reliability. Determining the benefits of various methods including time requirements, invasiveness and money cost (Svedahl \& MacIntosh, 2003).

Further in this article, disadvantages and benefits of some chosen non - invasive methods of defining AnT, with different protocols, are explained in accordance with their limits regarding original invasive methods (Table 1).

\section{Anaerobic threshold using Heart Rate}

In 1982 Conconi et al. developed one test that included 210 trained people. Research subjects needed to complete this test running in a sport track with an initial speed of $12-14 \mathrm{~km} / \mathrm{hr}$ and increase their speed velocity at $0.5 \mathrm{~km} / \mathrm{hr}$ every $200 \mathrm{~m}$ Authors discovered a linear incremental of $\mathrm{HR}$ at sub maximal velocities, however this not occur at maximal velocities (Conconi et al., 1982). In other words, at higher intensities the HR does not show a lineal incremental related with workload, although demonstrated a deflection in $\mathrm{HR}$ called heart rate deflection point $\left(\mathrm{HR}_{\mathrm{DP}}\right)$.

The $\mathrm{HR}_{\mathrm{DP}}$ has been identified to the point where it slope values began to decrease and there is an evident loss of the linear slope values of HR (Bodner \& Rhodes, 2000). Visual inspection seems to be a good method to determinate this break point by two or more experienced researchers, but mathematical or computer procedures possible present better accuracy (Sentija, Vucetic, \& Markovic, 2007). Any of these methods can be used for sport performance predictions.

According to Vachon, Basse and Clarke (1999) conducted a research about the validity of $\mathrm{HR}_{\mathrm{DP}}$ as predictor of lactate threshold (LT). Eight male distance runner completed three different treadmills protocols and the Conconi test in track; they found the $\mathrm{HR}_{\mathrm{DP}}$ at maximal speed in all subjects in track. The same did not occur in the conventional laboratory test, in this scenario only half of sportsman present the $\mathrm{HR}_{\mathrm{DP}}$. Author referred his findings as consequence of shortening of stages in track protocol (Vachon, et al., 1999). Bonder and Rodhes (2000) argued that $\mathrm{HR}_{\mathrm{DP}}$ concluding that these controversial results are due to the different protocols used to analyze them. Table 1 shows summaries about studies performed on athletes and their relationship with physiological variables, non-spirographic values can be a good predictor of anaerobic threshold but not in all cases. 
Table 1. Correlation between invasive and different non - invasive methods to estimate anaerobic threshold

\begin{tabular}{|c|c|c|c|c|c|c|}
\hline Author & $\mathbf{N}$ & Sport & Sex & Protocol & Contrast & Results \\
\hline $\begin{array}{l}\text { Oliveira et al., } \\
(2015)\end{array}$ & 9 & Cyclist & Male & $\begin{array}{l}\text { Incremental Exercise } \\
\text { Cycloergometer }\end{array}$ & $\begin{array}{l}\text { Blood } \\
\text { lactate }\end{array}$ & $\begin{array}{l}\text { Saliva lactate explains } 93.4 \% \\
\text { of blood lactate }\end{array}$ \\
\hline $\begin{array}{l}\text { Bocanegra et } \\
\text { al., (2012) }\end{array}$ & 12 & Swimmers & Male & $\begin{array}{l}\text { Incremental Exercise } \\
50 \mathrm{~m} \text { pool }\end{array}$ & $\begin{array}{l}\text { Blood } \\
\text { lactate }\end{array}$ & $\begin{array}{l}\text { Correlate } 0.91 \text {. Blood lactate } \\
\text { almost twice as high than } \\
\text { saliva }\end{array}$ \\
\hline $\begin{array}{l}\text { Vučetić et al., } \\
(2014)\end{array}$ & 48 & Runners & Male & Treadmill incremental & $\begin{array}{l}\text { Ventilatory } \\
\text { threshold }\end{array}$ & $\begin{array}{l}\text { Correlate } 0.88 \text { with Heart } \\
\text { deflection point }\end{array}$ \\
\hline $\begin{array}{l}\text { Debray \& Dey } \\
(2007)\end{array}$ & 26 & $\begin{array}{l}\text { Football and } \\
\text { Swimmers }\end{array}$ & $\begin{array}{l}\text { Male } \\
\text { boys }\end{array}$ & Treadmill incremental & $\begin{array}{l}\text { Ventilatory } \\
\text { threshold }\end{array}$ & $\begin{array}{l}\text { Correlate } 0.94 \text { with Heart } \\
\text { deflection point in most but } \\
\text { not all subjects }\end{array}$ \\
\hline $\begin{array}{l}\text { Vachon et } \\
\text { al.,(1999) }\end{array}$ & 8 & Runners & Male & $\begin{array}{l}\text { Treadmill incremental, } \\
\text { Conconi test }\end{array}$ & $\begin{array}{l}\text { Lactate } \\
\text { threshold }\end{array}$ & $\begin{array}{l}\text { Heart deflection point was } \\
\text { not accurate predictor of } \\
\text { lactate threshold }\end{array}$ \\
\hline $\begin{array}{l}\text { Pinto et } \\
\text { al.,(2016) }\end{array}$ & 27 & Physical activity & Male & Water Cycloergometer & $\begin{array}{l}\text { Ventilatory } \\
\text { threshold }\end{array}$ & $\begin{array}{l}\text { Moderate but significative } \\
\text { correlation }(\mathrm{r}=0.57) \text { with } \\
\text { HRDP }\end{array}$ \\
\hline $\begin{array}{l}\text { Bucheit et al., } \\
(2007)\end{array}$ & 72 & Sort sport & Male & Treadmill incremental & $\begin{array}{l}\text { Ventilatory } \\
\text { threshold }\end{array}$ & $\begin{array}{l}\text { Moderate but significative } \\
\text { correlation }(\mathrm{r}=0.51) \text { with } \\
\text { HRDP }\end{array}$ \\
\hline $\begin{array}{l}\text { Tekus et } \\
\text { al.,(2012) }\end{array}$ & 16 & $\begin{array}{l}\text { Endurance and } \\
\text { non athletes }\end{array}$ & $\begin{array}{l}\text { Male- } \\
\text { Female }\end{array}$ & Astrand treadmill test & $\begin{array}{l}\text { Blood } \\
\text { lactate }\end{array}$ & $\begin{array}{l}\text { Stronger correlation in } \\
\text { athletes }(\mathrm{r}=0.51)\end{array}$ \\
\hline $\begin{array}{l}\text { Taylor et al., } \\
\text { (1994) }\end{array}$ & 10 & Trained & Males & $\begin{array}{l}\text { Treadmill incremental } \\
\text { test }\end{array}$ & $\begin{array}{l}\text { Blood } \\
\text { lactate }\end{array}$ & No correlation with EMG \\
\hline
\end{tabular}

On the other hand, it has also been reported that $\mathrm{HR}_{\mathrm{DP}}$ can be a good predictor of AnT, since there are no differences in determining it by ventilatory methods or $\mathrm{HR}_{\mathrm{DP}}$ (Pinto et al., 2016) and also it is a good estimator of maximal lactate steady state (de Assis et al., 2015). Certainly, there is a moderate but significant correlation $(\mathrm{r}=0.51)$ found between $\mathrm{HR}_{\mathrm{DP}}$ and ventilatory threshold in young sport males according to (Buchheit, Solano, \& Millet, 2007). However, this phenomenon can be influenced by several factors including left ventricular ejection fraction. Pokan et al.(1993), found an absence in $\mathrm{HR}_{\mathrm{DP}}$, explained from the decreased efficiency of the left ventricle and it's offset by increasing the HR in healthy adults (Pokan et al., 1993).

Extended works about $\mathrm{HR}_{\mathrm{DP}}$ shows high correlation $(\mathrm{r}=0.88)$ with ventilator threshold in sprinters, middle and long distance (Vucetić, Sentija, Sporis, Trajković, \& Milanović, 2014). As well in two different protocols standard treadmill test (increment 1 $\mathrm{km} / \mathrm{h}$ every $60 \mathrm{~s}$ ) and fast treadmill test (increment 1 $\mathrm{km} / \mathrm{h}$ every $30 \mathrm{~s}$ ), authors evaluating 51 subjects and
$\mathrm{HR}_{\mathrm{DP}}$ was evident in 47 (Sentija et al., 2007). Several authors conclude that $\mathrm{HR}_{\mathrm{DP}}$ may be an accurate predictor of AnT in most but not all subjects (Debray \& Dey, 2007)

It seems that $\mathrm{HR}_{\mathrm{DP}}$ it is an accurate way to determine AnT when considered: monitoring HR every 30 $\mathrm{s}$, incremental protocols with initial speeds of $8 \mathrm{~m} / \mathrm{s}$ increased from $1 \mathrm{~km} / \mathrm{h}$ every 30 or $60 \mathrm{~s}$ and consider to use track or field protocols, even to control variables becomes even more complex in this environment is the closest to reality where the athlete develops.

\section{Determination of AnT through saliva}

The measurement of electrolytes through saliva has been considered an alternative way to determine AnT according to Lopez-Chicharro et al. (Lopez-Chicharro, Legido, Alvarez, Serratosa, Bandres, \& Gamella, 1994). Authors used a sub maximal test in cycle ergometer and found high correlation (0.82) between saliva threshold and LT, saliva threshold and catecholamine threshold, and concluded that by measuring parameters in saliva is a good and 
non-invasive method to visualize AnT. Later, the same results was confirmed in children with no difference in blood lactate threshold and $\mathrm{Na}^{+}$and $\mathrm{Cl}^{+}$ measured in saliva (saliva threshold) in a field test (Lopez-Chicharro, Calvo, Alvarez, Vaquero, Bandres, \& Legido, 1995). The same occurred with the determination of lactate in saliva, high correlation (0.81) reported between this way to measure it and blood lactate assessment. Besides the authors point that 40 days after the saliva sample is taken it remains stable at $4^{\circ} \mathrm{C}$ (Segura, Javierre, Ventura, Lizarraga, Campos, \& Garrido, 1996).

In a progressive exercise protocol, subject performed until voluntary exhaustion and determination of blood and saliva lactate was assessment. The average values of saliva lactate were 6-20\% compared to blood lactate and shows a parallel evolution of both. Saliva lactate can explain $93.4 \%$ of the blood lactate (Oliveira, Oliveira, Manchado-Gobatto, \& Costa, 2015) and with this support the idea of using saliva as lactate determination. In swimmer occur the same, high correlation (0.91) between blood lactate and saliva lactate determination was found, the protocol consisted of eight series of $100 \mathrm{~m}$ freestyle with increase of velocity. Both samples were taken simultaneously (Bocanegra, Diaz, Teixeira, Soares, \& Espindola, 2012) and thus estimate the anaerobic threshold (Bortolini, De Agostini, Reis, Silva Lamounier, Blumberg, \& Espindola, 2009)

However, the determination of lactate in saliva could not be applicable in all populations. Is been reported that saliva lactate regarding blood lactate in athletes showed a stronger correlation $(\mathrm{r}=0.51)$ compared to sedentary people ( $r=0.38)$, mainly due to the physiological differences associated with adaptations in the central nervous system and circulatory system (Tékus et al., 2012)

According to Claver, Mirón and Capitán-Vallvey (2009) the technique and standardization of the measuring lactate in saliva has been developed, results showed a good alternative method to assess at a low cost, quick, selective and sensitive and does not require an extensive specialization.

\section{Using perceived exertion to determine Anaerobic Threshold}

Among the different techniques developed exist the Borg's scale, which has become one of most used techniques in perceived exertion, since mostly of parameters such lactate, HR, and electromyography, predicting through those values, how participants feel. However, it is recommended to be more accurate and ask directly to the participant how really he/she feels. However there is still controversy about the applicability of Borg's scale, for example, a patient with a given HR workload may choose "hard" in just walking exercise, but his HR in running can reach higher levels (Borg, 1982; Grant et al., 1999).

Though, Borg's Scale (a 15 points scale) has been used to determine the relationship between $\mathrm{HR}_{\mathrm{DP}}$ in 35 active males, but this was only possible with 24 participants authors reported at this point that views of Borgs 16 scale (e Silva, Dias, Franco, de Lima, \& da Silva Novaes, 2008). In other hand no differences were noticed in women in physical activity level in Borg's scale, both groups showed AnT closed to level 5 in Borg's 10 points scale (Zamunér et al., 2011). In coronary artery disease patients show 5-6 values in ventilator anaerobic threshold determination, and results may be explained by their physical condition (Forti, Zamunér, Kunz, Salviati, Nery, \& Silva, 2014)

In heart failure patients the exercise guided by the Borg scale maintains the patient's HR between the anaerobic threshold in the exercise training zone important parameter in this populations (Carvalho, Bocchi, \& Guimarães, 2009) and its use its recommended in physicians, physical therapist and medical staff for determining the intensity of resistance exercise in clinical practice (Mahler \& Rostan, 1990; Morishita, Yamauchi, Fujisawa, \& Domen, 2014)

\section{Electromyography (EMG) Analysis to AnT determination}

Electromyography analysis was used to determination of AnT in different populations and vastus lateralis regularly used for EMG, although sometimes cannot be explained or correlated due to an inter individual difference in the EMG. A progressive recruitment has been observed of fast twitch fibbers as work load increases (Helal, Guezennec, \& Goubel, 1987). Occurring similar results in ten trained males in an incremental exercise protocol, it seems that inter subject variability in EMG cannot predict lactate threshold, instead EMG break point was shown after the appearance of lactate threshold (Taylor \& Bronks, 1994)

Meanwhile different results were presented by Tyka et al., (Tyka, Pałka, Tyka, Cisoń, \& Szyguła, 2009) demonstrating a high correlation in EMG with 
lactate threshold $(r=0.91,0.96$ y 0.97$)$ respectively for three different temperature exercise protocol $(23,31$ y $37^{\circ}$ Celsius) in 15 males. Moreover the EMG activity could be used as an indicator of the AnT (Viitalaso, Luhtanen, Rahkila, \& Rusko, 1985). Matsumoto, Ito \& Moritani (1991) used EMG fatigue threshold to determine AnT including 20 female college students, the sample consisted in high trained endurance athletes and sedentary individuals in cyclo-ergometer. Authors reported no difference in AnT and EMG at a given oxygen consumption, instead high correlation $(\mathrm{r}=0.823)$, concluding EMG it is an attractive alternative to measure AnT (Matsumoto, Ito, \& Moritani, 1991)

\section{CONCLUSIONS}

Coaches and athletes with different economic power often don't have equal terms on start as is anticipated in sport rules in all sport branches. One, and important part of sport is a process of athletes testing in expensive laboratories. Those testing are unreachable for large part of athlete population, in better part of their carriers. Athletes are recognised from a system, almost always, after reaching good results, so almost always too late. Anaerobic threshold is one of most important milestone for modern process of training. There are many ways to determine

\section{REFERENCES}

1. Bocanegra, O.L., Diaz, M.M., Teixeira, R.R., Soares, S.S., \& Espindola, F.S. (2012). Determination of the lactate threshold by means of salivary biomarkers: chromogranin A as novel marker of exercise intensity. European Journal of Applied Physiology, 112(9), 3195- 3203.

2. Bodner, M.E., \& Rhodes, E.C. (2000). A review of the concept of the heart rate deflection point. Sports Medicine, 30(1), 31-46.

3. Borg, G.A. (1982). Psychophysical bases of perceived exertion. Medicine \& Sciences in Sports \& Exercise, 14(5), 377-381.

4. Bortolini, M.S., De Agostini, G.G., Reis, I.T., Silva Lamounier, R.P.M., Blumberg, J.B., \& Espindola, F.S. (2009). Total protein of whole saliva as a biomarker of anaerobic threshold. Research quarterly for exercise and sport, 80(3), 604-610.
AnT in substitution for expensive and invasive methods, further with high correlation (Claver, Mirón, \& Capitán-Vallvey, 2009). Determination of AnT through non - invasive methods such as heart rate, saliva electrolytes or lactate, perceived exertion and electromyography among others, can predict sports performance with good reproducibility in almost all populations, redirect training and can help coaches and athletes to be more competitive. However, each of this parameter has some particularities and controversy due to different results reported by specialist. These differences may be explained by protocol testing used, sport level sample, starting intensity or number of levels among others. Despite this, they still have good reproducibility and applications on field based test protocols. Mentioned tests could be used in a large scale, and more often, with paying attention about level of correlation with original invasive tests, and percent of possible mistake in estimation process. Cheaper, and simpler tests (instead subjective estimation of training load) allows using more precise planning and changing volume, and intensity of training, for coaches, and athletes, that have needed level of education and less money. Athletes comfort, and possible high frequency of testing during non - invasive test, also must be emphasized as an advantage during training evaluation process.

5. Buchheit, M., Solano, R., \& Millet, G.P. (2007). Heart-rate deflection point and the second heartrate variability threshold during running exercise in trained boys. Pediatric Exercise Science, 19(2),192-204.

6. Carvalho, V.O., Bocchi, E.A., \& Guimarães, G.V. (2009). The Borg Scale as an Important Tool of Self-Monitoring and Self-Regulation of Exercise Prescription in Heart Failure Patients During Hydrotherapy A Randomized Blinded Controlled Trial. Circulation Journal, 73(10), 1871-1876.

7. Claver, J.B., Mirón, M.V., \& Capitán-Vallvey, L. (2009). Disposable electrochemiluminescent biosensor for lactate determination in saliva. Analyst, 134(7), 1423-1432.

8. Conconi, F., Ferrari, M., Ziglio, P., Droghetti, P., Borsetto, C., Casoni, I., . . Paolini, A. (1982). 
Determination of the anaerobic threshold by a noninvasive field test in running and other sport activities: Paper presented at the Current topics in sports medicine, World Congress, Vienna.

9. Davis, J.A. (1985). Anaerobic threshold: review of the concept and directions for future research. Medicine and Science in Sports and Exercise, 17(1), 6-21.

10. Damnjanović, I. (2016). Neinvazivne i invazivne metode za procenu individualnog anaerobnog praga [Non-invasive and invasive methods for assessing individual anaerobic threshold. In Serbian] (Unpublished Bchler Thesis). Univerzitet $\mathrm{u}$ Beogradu, Fakultet Sporta i fizičkog vaspitanja.

11. de Assis, P.P., Piubelli, C.V., Mello, R.G., Pereira, D.J., Guerra, R., \& Silva, M.d.A.P. (2015). The relationship between the heart rate deflection point test and maximal lactate steady state. The Journal of sports medicine and physical fitness, 11, 124128.

12. Debray, P., \& Dey, S.K. (2007). A comparison of the point of deflection from linearity of heart rate and the ventilatory threshold in the determination of the anaerobic threshold in Indian boys. Journal of physiological anthropology, 26(1), 31-37.

13. e Silva, A.C., Dias, M.R.C., Franco, V.H.P., de Lima, J.R.P., \& da Silva Novaes, J. (2008). Estimate of the threshold of Conconi through the Borg's scale in cycloergometer. Fitness \& performance journal, 4 (4), 215-219.

14. Forti, M., Zamunér, A.R., Kunz, V.C., Salviati, M.R., Nery, T.A.G., \& Silva, E.d. (2014). Ratings of perceived exertion at anaerobic threshold in patients with coronary artery disease. Fisioterapia e Pesquisa, 21(2), 113-119.

15. Grant, S., Aitchison, T., Henderson, E., Christie, J., Zare, S., McMurray, J., \& Dargie, H. (1999). A comparison of the reproducibility and the sensitivity to change of visual analogue scales, Borg scales, and Likert scales in normal subjects during submaximal exercise. Chest Journal, 116(5), 1208-1217.

16. Grujić, N., Barak, O., Drapšin, M., Karaba-Jakovljević, D., Klašnja, A., Lukač, D., Baćanović, M., Brkić, P., Vasić, G., Drenjančević, I., Ibročić, P., Jakovljević, Đ., Mitrović, D., Ponorac, N., Radoš, B., Rajković, Ž., Ćeranić, S. (2017). Fiziologija sporta [Sport Physiology. In Serbian]. Novi Sad: Univerzitet u Novom Sadu, Medicinski Fakultet.
17. Helal, J., Guezennec, C., \& Goubel, F. (1987). The aerobic-anaerobic transition: re-examination of the threshold concept including an electromyographic approach. European journal of applied physiology and occupational physiology, 56(6), 643-649.

18. Ignjatović, A., Hofmann, P., \& Radovanović, D. (2008). Non-invasive determination of the anaerobic threshold based on the heart rate deflection point. Facta universitatis-series: Physical Education and Sport, 6(1), 1-10.

19. Ilić, N., \& Rajković, Ž. (2009): Monitoring treninga kroz puls i brzinu u različitim zonama intenziteta u cikličnim sportovima tipa izdržljivosti [Monitoring the training through the pulse and intensity in different zones in a cyclic endurance sports type. In Serbian], First national seminar for sports coaches of the Republic of Serbia, (pp. 136-154). Belgrade: Republic Institute for Sports.

20. Lopez-Chicharro, J., Calvo, F., Alvarez, J., Vaquero, A., Bandres, F., \& Legido, J. (1995). Anaerobic threshold in children: determination from saliva analysis in field tests. European journal of applied physiology and occupational physiology, 70(6), 541-544.

21. Lopez-Chicharro, J., Legido, J. C., Alvarez, J., Serratosa, L., Bandres, F., \& Gamella, C. (1994). Saliva electrolytes as a useful tool for anaerobic threshold determination. European journal of applied physiology and occupational physiology, 68(3), 214-218.

22. Mahler, P., \& Rostan, A. (1990). L'effort perçu: corrélation avec le seuil anaérobie et utilité dans un programme d'entraînement. Schweizerische Zeitschrift für Sportmedizin, 38(4), 187-191.

23. Matsumoto, T., Ito, K., \& Moritani, T. (1991). The relationship between anaerobic threshold and electromyographic fatigue threshold in college women. European journal of applied physiology and occupational physiology, 63(1), 1-5.

24. Morishita, S., Yamauchi, S., Fujisawa, C., \& Domen, K. (2014). Rating of perceived exertion for quantification of the intensity of resistance exercise. International Journal of Physical Medicine \& Rehabilitation, 1(172), 2.

25. Oliveira, L.d.S., Oliveira, S.F., Manchado-Gobatto, F.d.B., \& Costa, M.d.C. (2015). Salivary and blood lactate kinetics in response to maximal 
workload on cycle ergometer. Revista Brasileira de Cineantropometria \& Desempenho Humano, 17(5), 565-574.

26. Pinto, S.S., Brasil, R.M., Alberton, C.L., Ferreira, H.K., Bagatini, N.C., Calatayud, J., \& Colado, J.C. (2016). Noninvasive Determination of Anaerobic Threshold Based on the Heart Rate Deflection Point in Water Cycling. The Journal of Strength \& Conditioning Research, 30(2), 518-524.

27. Pokan, R., Hofmann, P., Preidler, K., Leitner, H., Dusleag, J., Eber, B., . . Klein, W. (1993). Correlation between inflection of heart rate/work performance curve and myocardial function in exhausting cycle ergometer exercise. European journal of applied physiology and occupational physiology, 67(5), 385-388.

28. Segura, R., Javierre, C., Ventura, J., Lizarraga, M., Campos, B., \& Garrido, E. (1996). A new approach to the assessment of anaerobic metabolism: measurement of lactate in saliva. British Journal of Sports Medicine, 30(4), 305-309.

29. Sentija, D., Vucetic, V., \& Markovic, G. (2007). Validity of the modified Conconi running test. International journal of sports medicine, 28(12), 1006-1011.

30. Svedahl, K., \& MacIntosh, B.R. (2003). Anaerobic threshold: the concept and methods of measurement. Canadian Journal of Applied Physiology, 28(2), 299-323.

31. Taylor, A., \& Bronks, R. (1994). Electromyographic correlates of the transition from aerobic to anaerobic metabolism in treadmill running. European journal of applied physiology and occupational physiology, 69(6), 508-515.

32. Tékus, É., Kaj, M., Szabó, E., Szénási, N., Kerepe- si, I., Figler, M., .. . Wilhelm, M. (2012). Comparison of blood and saliva lactate level after maximum intensity exercise. Acta Biologica Hungarica, 63(Supplement 1), 89-98.

33. Tyka, A., Pałka, T., Tyka, A., Cisoń, T., \& Szyguła, Z. (2009). The influence of ambient temperature on power at anaerobic threshold determined based on blood lactate concentration and myoelectric signals. International journal of occupational medicine and environmental health, 22(1), 1-6.

34. Vachon, J.A., Bassett, D.R., \& Clarke, S. (1999). Validity of the heart rate deflection point as a predictor of lactate threshold during running. Journal of applied physiology, 87(1), 452-459.

35. Viitalaso, J. T., Luhtanen, P., Rahkila, P., \& Rusko, H. (1985). Electromyographic activity related to aerobic and anaerobic threshold in ergometer bicycling. Acta physiologica scandinavica, 124(2), 287-293.

36. Vucetić, V., Sentija, D., Sporis, G., Trajković, N., \& Milanović, Z. (2014). Comparison of ventilation threshold and heart rate deflection point in fast and standard treadmill test protocols. Acta clinica Croatica, 53(2), 190-203.

37. Wasserman, K., \& McIlroy, M.B. (1964). Detecting the threshold of anaerobic metabolism in cardiac patients during exercise. The American journal of cardiology, 14(6), 844-852.

38. Zamunér, A.R., Moreno, M.A., Camargo, T.M., Graetz, J.P., Rebelo, A.C., Tamburús, N.Y., \& da Silva, E. (2011). Assessment of subjective perceived exertion at the anaerobic threshold with the Borg CR-10 scale. Journal of Sports Science and Medicine, 10(1), 130-136. 


\section{NICHT-SPIROGRAPHISCHE UND NICHT-INVASIVE METHODEN FÜR DIE EINSCHÄTZUNG DER ANAEROBEN SCHWELLE}

\section{Zusammenfassung}

In der Welt von Sportuntersuchungen gibt es verschiedene Wege für die Einschätzung der Körperverfassung - die Palette reicht von teuren labor-invasiven Methoden bis zu billigen, nicht-invasiven Methoden im Gelände. Tests, die auf nicht-invasiven Methoden gründen, haben eine gute Zuverlässigkeit und einen niedrigen Preis für die Anwendung von physiologischen Parametern wie zum Beispiel: Puls, Elektrolyte oder Laktat aus Speichel, wahrgenommene Anstrengung und Elektromiographie. Diese Parameter können für die Einschätzung der anaeroben Schwelle (AnT) angewendet werden, die für Prognosen von Sportleistungen, Umgestaltung von Trainings verwendet wird und Trainern und Sportlern helfen kann, wettbewerbsfähiger zu werden. Jeder dieser Parameter hat jedoch seine Eigentümlichkeiten und Kontroversen wegen unterschiedlicher Ergebnisse, die von Experten präsentiert werden. Diese Unterschiede können unter anderem durch Prüfungen der angewendeten Protokolle, durch die Musterebene der Sportler, die anfängliche Intensität oder die Anzahl der Qualitätsebenen der Sportler erklärt werden. Trotz allem haben sie auch weiterhin eine gute Wiederholbarkeit und Anwendung auf Prüfungen der Protokolle, die auf den Geländebedingungen gründen. Die angeführten Tests können in bedeutendem Maße angewendet werden, wobei die Korrelationsstufe mit originellen invasiven Tests und der Prozentsatz möglicher Fehler im Einschätzungsprozess beachtet werden müssen. Billigere und einfachere Tests (anstatt subjektiver Einschätzungen der Trainingsbelastung) ermöglichen eine präzisere Planung, änderen den Umfang und die Intensität des Trainings für den Trainer und den Sportler und fordern somit eine niederigere Bildungsebene und weniger finanzielle Mittel. Der Komfort der Sportler und mögliche häufigere Untersuchungen im Laufe von nicht-invasiven Tests können als Vorteil während des Evaluierungsprozesses von Trainings hervorgehoben werden.

Schlüsselwörter: PULS / SPEICHEL / WAHRNEHMUNG DER ANSTRENGUNG / ELEKTROMIOGRAPHIE / LAKTAT IM BLUT / ERGOMETRIE

Received: 24.04.2017.

Accepted: 10.05.2017. 


\title{
НЕСПИРОГРАФСКЕ ИЛИ НЕИНВАЗИВНЕ МЕТОДЕ ЗА ПРОЦЕНУ АНАЕРОБНОГ ПРАГА
}

\author{
Раул Хосе Најера-Лонгориа ${ }^{1}$, Омар Рикардо Ортиз Гомез ${ }^{1}$, Хезус Салвадор Лопез Алонсо ${ }^{1}$ Рамон
} Кандиа-Лујан ${ }^{1}$, Оскар Њуњез Енрикуез ${ }^{2}$, Роберто Гутиерез Мартинез ${ }^{1}$, Жељко М. Рајковић

${ }^{1}$ Аутономни универзитет Чихуахуа, Факултет наука о физичкој култури, Мексико

2 Државни универзитет Њу Мексико, САД

${ }^{3}$ Универзитет у Београду, Факултет спорта и физичког васпитања

\begin{abstract}
Сажеатк
У свету спортских истраживања постоје различити начини да се одреди физичка кондиција, почев од скупих лабораторијских инвазивних метода до јефтиних, неинвазивних метода на терену. Неинвазивно испитивање на терену даје добру поузданост и није скупо, а између осталих, користе се физиолошки параметари као што су: срчана фреквенција, електролити пљувачке или лактат, доживљени напор и електромиографија. Ови параметри се могу користити за процену анаеробног прага (АнТ) како би се предвидео спортски учинак, преусмерио тренинг, а може и да помогне тренерима и спортистима да буду конкурентнији. Међутим, сваки од ових параметара има неке особености и контроверзе услед различитих резултата које стручњаци пријављују. Ове разлике се могу, између осталог, објаснити протоколом тестирања који се користи, узорком спортског нивоа, почетним интензитетом или бројем нивоа. Упркос томе, они и даље имају добру поновљивост и примену у протоколима тестирања на терену. Наведена испитивања се могу применити у великом обиму, и чешће, са пажњом усмереном на степен корелације са првобитним инвазивним тестовима, као и на проценат могућих грешака у процесу процењивања. Јефтинија и једноставнија испитивања (уместо субјективне процене тренажног оптерећења) омогућавају тренерима и спортистима са мање новца прецизније планирање и мењање обима и интензитета тренинга. Осећај удобности који спортисти имају, као и евентуалне високе фреквенције испитивања током неинвазивног теста, морају се истаћи као предност током процеса евалуације тренинга.
\end{abstract}

КљУчНе речИ: СРЧАНА ФРЕКВЕНЦИЈА / ПЉУВАЧКА / ДОЖИВЉЕНИ НАПОР / ЕЛЕКТРОМИОГРАФИЈА / ЛАКТАТИ У КРВИ / ЕРГОМЕТРИЈА

\section{УВОД}

Најмање педесет година је прошло од када су Васерман и Меклори (Wasserman \& McIlroy, 1964) развили концепт анаеробног прага (АнТ) који је дефинисан као губитак између вентилационих елемената и радног оптерећења у оквиру потрошње кисеоника и поклапа се са горњом границом аеробног метаболизма појединца. Осим тога, овај параметар се односи на продужени учинак вежбања (Davis, 1985; Ignjatović, Hofmann, \& Radovanović, 2008; Wasserman \& McIlroy, 1964).

Значај одређивања анаеробног прага (АнТ) се не доводи у сумњу, међутим, и даље постоји контроверза око различитих облика утврђивања анаеробног прага. Постоје бројне методе за процену, почевши од инвазивних (лактат у крви) или неудобних и скупих (спирографија, електромиографија, магнетна резонанца) до неинвазивних метода (Bodner \& Rhodes, 2000; Lopez-Chicharro, Calvo, Alvarez, Vaquero, Bandres, \& Legido, 1995; de Assis, Piubelli, Mello, Pereira, Guerra, \& Silva, 2015). У овој подгрупи, АнТ се одређује путем пљувачке, доживљеног напора, одступања у срчаној фреквенцији, испитивања путем разговора, што одржава добру поузданост и то по ниској цени.

Циљ овог прегледног рада је да се представе различите неспирографске и неинвазивне методе 
којима се одређује анаеробни праг. Спроведено је претраживање различитих база података, укључујући EBSCO SportDiscus, са акцентом на појмовима као што су «анаеробни праг», «лактатни праг» и «вентилациони праг».

\section{МЕТОД}

У овом раду су коришћене библиографске, историјске и каузалне методе уз логичко, дедуктивно и индуктивно закључивање. Поред систематизације личног професионалног искуства у практичном одређивању анаеробног прага, такође је коришћена метода теоријске анализе.

\section{РЕЗУЛТАТИ И ДИСКУСИЈА}

Најважнија карактеристика анаеробног прага је да лактат у крви, након критичне тачке показује нагли пораст, што у блажој форми доводи до слабљења концентрације и координације, а у екстремним случајевима, до заустављања свих активности (Дамњановић, 2016). Дефинисање анаеробног прага за одређеног спортисту представља детерминанту за дозирање тренинга, углавном у спортовима у којима је издржљивост доминантна компонента (веслање, кану, трчање, бициклизам, пливање, итд), (Грујић и сар, 2017), али и у другим спортовима у одређеној фази припреме. На основу различитих параметара који су забележени на нивоу анаеробног прага, може се дефинисати специфично «изведени» АнТ, као што су брзина чамца током АнТ или фреквенција хода током АнТ, током одређеног времена или дужине деонице у веслању, за сваког веслача (Илић и Рајковић, 2009).

Постоји много различитих метода одређивања анаеробног прага. Да би дефинисали користан метод, он треба да буде спроводљив, а треба и да процени ширину прага са одређеном поузданошћу. Одређивање предности различитих метода обухвата временске захтеве, инвазивност и новчане трошкове (Svedahl \& MacIntosh, 2003).

Даље у овом раду, објашњени су недостаци и предности неких одабраних неинвазивних метода одређивања анаеробног прага, са различитим протоколима, а у складу са њиховим ограниче- њима у погледу првобитних инвазивних метода (Табела 1).

\section{Одређивање анаеробног прага помоћу срчане фреквенције}

Конкони и сарадници (Conconi et al., 1982), су креирали тест који је обухватао 210 утренираних људи. Испитаници у истраживању су изводили овај тест трчећи на спортској стази почетном брзином од $12-14 \mathrm{~km} / \mathrm{h}$ повећавајући брзину за $0.5 \mathrm{~km} / \mathrm{h}$ па сваких $200 \mathrm{~m}$. Аутори су открили линеарно повећање срчане фреквенције (XР) при субмаксималним брзинама, међутим, ово се није дешавало при максималним брзинама. Другим речима, при већим интензитетима ХР не показује линеарно повећање повезано са радним оптерећењем, иако се представљено одступање у ХР зове тачка одступања срчане фреквенције $\left(\mathrm{XP}_{\text {дп }}\right)$.

$\mathrm{XP}_{\text {дп }}$ се идентификује до тачке где вредности коефицијента смера (нагиб правца) почињу да опадају и постоји очигледан губитак линеарних вредности нагиба правца срчане фреквенције (XР) (Bodner \& Rhodes, 2000). Визулени преглед од стране два или више искусних истраживача се чини добрим методом за одређивање те преломне тачке, али математички или компјутерски поступци вероватно пружају већу тачност (Sentija, Vucetic, \& Markovic, 2007). Било који од ових метода може се користити за предвиђање спортског учинка.

Вахон, Бејс и Калрк (Vachon, Basse, \& Clarke, 1999) су спровели истраживање о валидности $\mathrm{XP}_{\text {дп }}$ као предиктора лактатног прага (ЛТ). Осам тркача на дуге и средње стазе је обавило три различита протокола на траци за трчање, као и Конконијев тест на атлетској стази; $\mathrm{XP}_{\text {дп }}$ је откривена при максималној брзини код свих испитаника на стази. То се није десило у конвенционалном лабораторијском тесту. У овом сценарију само се код

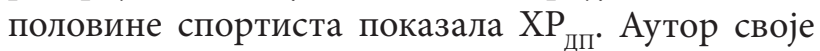
резултате наводи као последицу скраћења фаза у протоколу на стази (Vachon, Basse, \& Clarke, 1999). Бондер и Родхес (Bonder \& Rodhes, 2000) су расправљали $\mathrm{XP}_{\text {дп }}$ закључивши да су ти спорни резултати настали услед различитих протокола који се користе при анализи. Табела 1 приказује сажетак истраживања обављених на спортистима и њихову повезаност са физиолошким варијаблама. Неспирографске вредности могу бити добар предиктор анаеробног прага, али не у свим случајевима. 
Најера-Лонгориа Р.Ј., и сар., Неспирографске или неинвазивне..., ФИЗИЧКА КУЛТУРА 2017; 71 (1): 55-62

Табела 1. Корелација између инвазивних и неинвазивних метода за процену анаеробног прага

\begin{tabular}{|c|c|c|c|c|c|c|}
\hline Аутори & $\mathbf{N}$ & Спорт & Пол & Протокол & Коинтраст & Резултати \\
\hline $\begin{array}{l}\text { Oliveira et al., } \\
(2015)\end{array}$ & 9 & Бициклисти & Мушки & $\begin{array}{l}\text { Бицикл ергометар } \\
\text { са прогресивним } \\
\text { оптерећењима }\end{array}$ & Лактат у крви & $\begin{array}{l}\text { Лактат из пљувачке } \\
\text { објашњава 93.4\% } \\
\text { лактата у крви. }\end{array}$ \\
\hline $\begin{array}{l}\text { Bocanegra et } \\
\text { al., (2012) }\end{array}$ & 12 & Пливачи & Мушки & $\begin{array}{l}\text { Вежбе са повећањем } \\
\text { интензитета у } \\
\text { базену } 50 \mathrm{~m}\end{array}$ & Лактат у крви & $\begin{array}{l}\text { Корелација 0.91. лактат } \\
\text { у крви скоро дупло већа } \\
\text { него пљувачком. }\end{array}$ \\
\hline $\begin{array}{l}\text { Vučetić et al., } \\
(2014)\end{array}$ & 48 & Тркачи & Мушки & Тредмил са нагибом & $\begin{array}{l}\text { Вентилациони } \\
\text { анаеробни праг }\end{array}$ & $\begin{array}{l}\text { Корелација } 0.88 \text { са } \\
\text { тачком дефлексије срца. }\end{array}$ \\
\hline $\begin{array}{l}\text { Debray \& Dey } \\
(2007)\end{array}$ & 26 & $\begin{array}{l}\text { Фудбалери и } \\
\text { пливачи }\end{array}$ & $\begin{array}{l}\text { Мушки } \\
\text { дечаци }\end{array}$ & Тредмил са нагибом & $\begin{array}{l}\text { Вентилациони } \\
\text { анаеробни праг }\end{array}$ & $\begin{array}{l}\text { Корелација } 0.94 \text { са } \\
\text { тачком дефлексије срца } \\
\text { у већини случајева. }\end{array}$ \\
\hline $\begin{array}{l}\text { Vachon et } \\
\text { al.,(1999) }\end{array}$ & 8 & Тркачи & Мушки & $\begin{array}{l}\text { Тредмил са нагибом, } \\
\text { Конкони тест }\end{array}$ & $\begin{array}{l}\text { Лактатни } \\
\text { анаеробни праг }\end{array}$ & $\begin{array}{l}\text { Тачка дефлексије срца } \\
\text { није била прецизан } \\
\text { предиктор анаеробног } \\
\text { прага. }\end{array}$ \\
\hline $\begin{array}{l}\text { Pinto et } \\
\text { al.,(2016) }\end{array}$ & 27 & $\begin{array}{l}\text { Физичка } \\
\text { активност }\end{array}$ & Мушки & $\begin{array}{l}\text { Водени бицикл } \\
\text { ергометар }\end{array}$ & $\begin{array}{l}\text { Вентилациони } \\
\text { анаеробни праг }\end{array}$ & $\begin{array}{l}\text { Средња, али значајна } \\
\text { корелација }(\mathrm{r}=0.57) \mathrm{ca} \\
\text { тачком дефлексије срца. }\end{array}$ \\
\hline $\begin{array}{l}\text { Bucheit et al., } \\
(2007)\end{array}$ & 72 & Sort sport & Мушки & Тредмил са нагибом & $\begin{array}{l}\text { Вентилациони } \\
\text { анаеробни праг }\end{array}$ & $\begin{array}{l}\text { Средња, али значајна } \\
\text { корелација }(\mathrm{r}=0.51) \mathrm{ca} \\
\text { тачком дефлексије срца. }\end{array}$ \\
\hline $\begin{array}{l}\text { Tekus et } \\
\text { al.,(2012) }\end{array}$ & 16 & $\begin{array}{l}\text { Издржљивост и } \\
\text { неспортисти }\end{array}$ & $\begin{array}{l}\text { Мушки- } \\
\text { Женски }\end{array}$ & $\begin{array}{l}\text { Астранд тредмил } \\
\text { тест }\end{array}$ & Лактат у крви & $\begin{array}{l}\text { Јача корелација код } \\
\text { спортиста }(\mathrm{r}=0.51) .\end{array}$ \\
\hline $\begin{array}{l}\text { Taylor et al., } \\
\text { (1994) }\end{array}$ & 10 & Тренирани & Мушки & Тредмил са нагибом & Лактат у крви & $\begin{array}{l}\text { Нема корелације са } \\
\text { ЕМГ. }\end{array}$ \\
\hline
\end{tabular}

Са друге стране, такође је пријављено да $\mathrm{XP}_{\text {дп }}$ може бити добар предиктор анаеробног прага, пошто нема разлике у њеном одређивању помоћу вентилационих метода или $\mathrm{XP}_{\text {дп }}$ (Pinto et al., 2016), а такође и за добру процену максималног нивоа одржавања лактата стабилним (de Assis et al., 2015). Наравно, постоји и умерена, али значајна корелација $(\mathrm{r}=0.51)$ која је откривена између $\mathrm{XP}_{\text {дп }}$ и вентилационог прага код младих спортиста према Бухету и сарадницима (Buchheit, Solano, \& Millet, 2007). Међутим, на ову појаву може утицати неколико фактора укључујући ејекциону фракцију леве коморе. Покан и сарадници (Pokan et al., 1993) су открили одсуство ХР се објашњава смањеном ефикасношћу леве коморе и њеним компензовањем путем појачане срчане фреквенције код здравих одраслих особа.

Опширни радови о $\mathrm{XP}_{\text {дп }}$ показују високу корелацију $(r=0.88)$ са вентилационим прагом код спринтера, тркача на средње и дуге стазе (Vučetić,
Sentija, Sporis, Trajković, \& Milanović, 2014). Такође у два различита протокола стандардног теста на тредмил траци (повећање од $1 \mathrm{~km} / \mathrm{h}$ на сваких 60 s) и брзог теста на траци за трчање (повећање од $1 \mathrm{~km} / \mathrm{h}$ на сваких $30 \mathrm{~s}$ ), аутори су оцењивали 51 испитаника и $\mathrm{XP}_{\text {дп }}$ је била евидентна код њих 47 (Sentija et al., 2007). Неколико аутора закључује да $\mathrm{XP}_{\text {дп }}$ може бити прецизан предиктор анаеробног прага код већине, али не и код свих испитаника (Debray \& Dey, 2007).

Чини се да је $\mathrm{XP}_{\text {дп }}$ прецизан начин за утврђивање анаеробног прага када се у обзир узму: праћење срчане фреквенције сваких 30 c, инкрементални протоколи са почетним брзинама од $8 \mathrm{~m} / \mathrm{s}$ које се повећавају за $1 \mathrm{~km} / \mathrm{h}$ на сваких 30 или $60 \mathrm{~s}$, и сматра се да се користе протоколи на стази или терену, чак и контролисање варијабли постаје још сложеније у овом окружењу које је најближе стварности у којој се спортиста развија. 


\section{Утврђивање анаеробног прага (АнТ) пу- тем пљувачке}

Мерење електролита путем пљувачке се сматра алтернативним начином за утврђивање АнТ према Лопез-Ћићаро и сарадници (Lopez-Chicharro, Legido, Alvarez, Serratosa, Bandres, \& Gamella, 1994). Аутори су користили субмаксимални тест на бицикл ергометру и открили високу корелациjу (0.82) између прага пљувачке и ЛТ (лактатног прага), прага пљувачке и прага катехоламина, и закључили да је мерење параметара у пљувачки добра и неинвазивна метода за визуелизацију анаеробног прага. Касније, исти резултати су потврђени код деце без разлике у прагу лактата у крви и $\mathrm{Na}^{+}$i $\mathrm{Cl}^{+}$мерених у пљувачки (праг пљувачке) на испитивању на терену (Lopez-Chicharro, Calvo, Alvarez, Vaquero, Bandres, \& Legido, 1995). Исто се десило код одређивања лактата у пљувачки, висока корелација (0.81) је нађена између овог начина мерења и процењивања лактата у крви. Поред тога, аутори напомињу да 40 дана након узимања узорка пљувачке она остаје стабилна на температури од $4{ }^{\circ} \mathrm{C}$ (Segura, Javierre, Ventura, Lizarraga, Campos, \& Garrido, 1996).

У протоколу прогресивног вежбања испитаници су изводили вежбе до добровољног отказа и процењивано је утврђивање лактата у крви и пљувачки. Просечне вредности лактата пљувачке износиле су 6-20\% у односу на лактат у крви и приказује се паралелни пораст оба. Лактатом пљувачке се може објаснити $93.4 \%$ лактата у крви (Oliveira, Oliveira, Manchado-Gobatto \& Costa, 2015) и то подржава идеју коришћења пљувачке у одређивању лактата. Код пливача се јавља исто, откривена је висока корелација (0.91) између лактата у крви и одређивања лактата у пљувачки, протокол се састојао од осам серија од 100 м слободним стилом уз повећање брзине. Оба узорка су узета истовремено (Bocanegra, Diaz, Teikeira, Soares, \& Espindola, 2012) и тако је процењен анаеробни праг (Bortolini, De Agostini, Reis, Silva Lamounier, Blumberg, \& Espindola, 2009)

Међутим, одређивање лактата у пљувачки се не би могло применити код свих популација. Нађено је да лактат у пљувачки у односу на лактат у крви показује већу корелацију ( $\mathrm{r}=0.51)$ код спортиста у поређењу са седентарним људима ( $\mathrm{r}=0.38)$, углавном због физиолошких разлика повезаних са адаптацијама у централном нервном систему и систему крвотока ( Tékus et al., 2012).
Према Клејверу и сарадницима (2009), техника и стандардизација мерења лактата у пљувачки се развијају, резултати су показали добар алтернативни метод процене који је јефтин, брз, селективан и сензитиван и не захтева опширну специјализацију (Claver, Mirón, \& Capitán-Vallvey, 2009).

\section{Коришћење доживљеног напора у одређивању анаеробног прага}

Међу различитим техникама које су креиране, постоји и Боргова скала, која је постала једна од најзаступљенијих техника што се тиче доживљеног напора, пошто већина параметара као што су лактат, срчана фреквенција и електромиографија, предвиђају, кроз те вредности, како се учесници осећају. Међутим, препоручује се већа прецизност, као и то да се учесник/ца директно упита како се заиста осећа. Међутим, још увек је спорна применљивост Боргове скале, на пример: пацијент са датим XР оптерећењем може да означи вежбу која подразумева само ходање као „тешку”, али његов срчана фреквенција при трчању може достићи виши ниво (Borg, 1982; Grant et al., 1999).

Иако се Боргова скала (скала састављена од 15 ступњева) користила за утврђивање односа између $\mathrm{XP}_{\text {дп }}$ код 35 активних мушкараца, то је било могуће само код 24 учесника. Аутори су навели Боргову скалу са 16 ступњева (e Silva, Dias, Franko, de Lima, \& da Silva Novaes, 2008). С друге стране, нису примећене никакве разлике код жена у нивоу физичке активности према Борговој скали, обе групе су показале анаеробни праг (АнТ) приближан оцени 5 на Борговој скали од 10 ступњева (Zamunér et al., 2011). Код пацијената са обољењем коронарне артерије приказане су вредности 5-6 при одређивању вентилационог анаеробног прага, а резултати се могу приписати њиховом физичком стању (Forti, Zamunér, Kunz, Salviati, Nery, \& Silva, 2014)

Код пацијената са инсуфицијенцијом рада срца, вежбање вођено Борговом скалом одржава XР пацијента између анаеробног прага у тренажној зони вежठања као важан параметар у овој популацији (Carvalho, Bocchi, \& Guimaraes, 2009). Лекари, физиотерапеути и медицинско особље препоручују коришћење ове скале за одређивање интензитета вежби резистенције у клиничкој пракси (Mahler \& Rostan, 1990; Morishita, Iamauchi, Fujisava, \& Domen, 2014). 
Анализа електромиографије (ЕМГ) ради утврђивања анаеробног прага

Анализа електромиографије је коришћена за одређивање анаеробног прага у различитим популацијама и мишић вастус латералис је редовно коришћен за ЕМГ, иако се понекад не може објаснити или корелирати услед разлике међу појединачним ЕМГ. Прогресивно јачање је примећено код брзотрзајних мишићних влакана са порастом оптерећења (Helal, Guezennec \& Goubel, 1987). Како су се слични резултати јавили код десет утренираних мушкараца у инкременталном протоколу вежбања, чини се да варијабилност ЕМГ међу испитаницима не може да предвиди лактатни праг, уместо тога ЕМГ преломна тачка jе приказана након појаве лактатног прага (Taylor \& Bronks, 1994).

У међувремену Тика и сарадници (Tyka, Palka, Tyka, Cison, \& Szyguła, 2009) су представили различите резултате који показују високу корелацију ЕМГ са лактатним прагом $(\mathrm{r}=0.91,0.96 \mathrm{i}$ 0.97) појединачно за три различита температурна протокола вежбања (23, 31 и 370 Целзијуса) код 15 мушкараца. Штавише, ЕМГ активност се може користити као АнТ показатељ (Viitalaso, Luhtanen, Rahkila, \& Rusko, 1985). Матsумото, Ито и Моритани (Matsumoto, Ito, \& Moritani, 1991) су користили ЕМГ праг умора како би утврдили АнТ укључујући 20 студенткиња, узорак се састојао од веома утренираних спортисткиња и седентарних појединаца на бицикл ергометру. Аутори нису пријавили разлике у АнТ и ЕМГ при датој потрошњи кисеоника, уместо високе корелације $(\mathrm{p}=0.823)$, те су закључили да је ЕМГ атрактивна алтернатива за мерење анаеробног прага.

\section{ЗАКЉУЧАК}

Тренери и спортисти различите економске моћи често на почетку немају једнаке услове тренинга, као што је предвиђено спортским пра- вилима у свим спортским гранама. Један важан део спорта је поступак испитивања спортиста у скупим лабораторијама. Ова испитивања су недоступна за велики део спортске популације, у већем делу њихових каријера. Систем признаје спортисте, готово увек, тек након постизања добрих резултата, тако да је то скоро увек прекасно. Анаеробни праг је једна од најважнијих прекретница за модеран тренажни процес. Постоји много начина да се одреди анаеробни праг као замена за скупе и инвазивне методе, који поред тога имаjу високу корелацију (Claver, Mirón, \& Capitán-Vallvey, 2009). Одређивање анаеробног прага помоћу неинвазивних метода, као што су срчана фреквенција, електролити пљувачке или лактат, доживљени напор и електромиографија, између осталих, може да предвиди спортски учинак са добром поновљивошћу и применом у скоро свим популацијама, преусмери тренинг, а може и да помогне тренерима и спортистима да буду конкурентнији. Међутим, сваки од ових параметара има неке особености и контроверзе услед различитих резултата које стручњаци пријављују. Ове разлике се могу објаснити протоколима тестирања који се користе, узорком спортског нивоа, почетним интензитетом или бројем нивоа између осталог. Упркос томе, они и даље имају добру поновљивост и примену у протоколима испитивања на терену. Наведени тестови се могу користити у великом обиму, и чешће, са пажњом усмереном на степен корелације са првобитним инвазивним тестовима, као и на проценат могућих грешака у процесу процењивања. Јефтинија и једноставнија испитивања (уместо субјективне процене тренажног оптерећења) омогућавају прецизније планирање и мењање обима, као и интензитета тренинга, за тренере и спортисте са мање новца и мањим нивоом образовања. Осећај удобности који имају спортисти, као и евентуалне високе фреквенције испитивања у току неинвазивног теста, морају се истаћи као предност током процеса евалуације тренинга. 


\section{ЛИТЕРАТУРА}

1. Bocanegra, O.L., Diaz, M.M., Teixeira, R.R., Soares, S.S., \& Espindola, F.S. (2012). Determination of the lactate threshold by means of salivary biomarkers: chromogranin A as novel marker of exercise intensity. European Journal of Applied Physiology, 112(9), 3195-3203.

2. Bodner, M.E., \& Rhodes, E.C. (2000). A review of the concept of the heart rate deflection point. Sports Medicine, 30(1), 31-46.

3. Borg, G.A. (1982). Psychophysical bases of perceived exertion. Medicine \& Sciences in Sports \& Exercise, 14(5), 377-381.

4. Bortolini, M.S., De Agostini, G.G., Reis, I.T., Silva Lamounier, R.P.M., Blumberg, J.B., \& Espindola, F.S. (2009). Total protein of whole saliva as a biomarker of anaerobic threshold. Research quarterly for exercise and sport, 80(3), 604-610.

5. Buchheit, M., Solano, R., \& Millet, G.P. (2007). Heart-rate deflection point and the second heartrate variability threshold during running exercise in trained boys. Pediatric Exercise Science, 19(2),192-204.

6. Vachon, J.A., Bassett, D.R., \& Clarke, S. (1999). Validity of the heart rate deflection point as a predictor of lactate threshold during running. Journal of applied physiology, 87(1), 452-459.

7. Wasserman, K., \& McIlroy, M.B. (1964). Detecting the threshold of anaerobic metabolism in cardiac patients during exercise. The American journal of cardiology, 14(6), 844-852.

8. Viitalaso, J. T., Luhtanen, P., Rahkila, P., \& Rusko, H. (1985). Electromyographic activity related to aerobic and anaerobic threshold in ergometer bicycling. Acta physiologica scandinavica, 124(2), 287-293.

9. Vucetić, V., Sentija, D., Sporis, G., Trajković, N., \& Milanović, Z. (2014). Comparison of ventilation threshold and heart rate deflection point in fast and standard treadmill test protocols. Acta clinica Croatica, 53(2), 190-203.

10. Grant, S., Aitchison, T., Henderson, E., Christie, J., Zare, S., McMurray, J., \& Dargie, H. (1999). A comparison of the reproducibility and the sensitivity to change of visual analogue scales, Borg scales, and Likert scales in normal subjects during submaximal exercise. Chest Journal, 116(5), 1208-1217.
11. Грујић, Н., Барак, О., Драпшин, М., Караба-Јаковљевић, Д., Клашња, А., Лукач, Д., Баћановић, М., Бркић, П., Ваsић, Г., Дрењанчевић, И., Иброчић, П., Јаковљевић, Ћ., Митровић, Д., Понорац, Н., Радош, Б., Рајковић, Ж., Ћеранић, С. (2017). Физиолоїија sӣорӣа. Нови Сад: Универзитет у Новом Саду, Медицинкки Факултет.

12. Davis, J.A. (1985). Anaerobic threshold: review of the concept and directions for future research. Medicine and Science in Sports and Exercise, 17(1), 6-21.

13. Дамњановић, И. (2016). Неинвазивне и инвазивне метиоgе за ироиену индивияуалноі анаеробноі ӣpaīa (Необјавњени дипломкки рад). Универзитет у Београду, Факултет Спорта и физичког ваsпитања.

14. de Assis, P.P., Piubelli, C.V., Mello, R.G., Pereira, D.J., Guerra, R., \& Silva, M.d.A.P. (2015). The relationship between the heart rate deflection point test and maximal lactate steady state. The Journal of sports medicine and physical fitness, 11, 124-128.

15. Debray, P., \& Dey, S.K. (2007). A comparison of the point of deflection from linearity of heart rate and the ventilatory threshold in the determination of the anaerobic threshold in Indian boys. Journal of physiological anthropology, 26(1), 31-37.

16. e Silva, A.C., Dias, M.R.C., Franco, V.H.P., de Lima, J.R.P., \& da Silva Novaes, J. (2008). Estimate of the threshold of Conconi through the Borg's scale in cycloergometer. Fitness \& performance journal, 4 (4), 215-219.

17. Zamunér, A.R., Moreno, M.A., Camargo, T.M., Graetz, J.P., Rebelo, A.C., Tamburús, N.Y., \& da Silva, E. (2011). Assessment of subjective perceived exertion at the anaerobic threshold with the Borg CR-10 scale. Journal of Sports Science and Medicine, 10(1), 130-136.

18. Ignjatović, A., Hofmann, P., \& Radovanović, D. (2008). Non-invasive determination of the anaerobic threshold based on the heart rate deflection point. Facta universitatis-series: Physical Education and Sport, 6(1), 1-10. 
19. Илић, Н., \& Рајковић, Ж. (2009): Мониторинг тренинга кроз пуль и брзину у различитим зонама интензитета у цикличним мпортовима типа издржљивоsти. Први национални seминар за sпортsке тренере Републике Србије, (sтр. 136-154). Београд: Републички инsтитут за мпорт.

20. Lopez-Chicharro, J., Calvo, F., Alvarez, J., Vaquero, A., Bandres, F., \& Legido, J. (1995). Anaerobic threshold in children: determination from saliva analysis in field tests. European journal of applied physiology and occupational physiology, 70(6), 541-544.

21. Lopez-Chicharro, J., Legido, J. C., Alvarez, J., Serratosa, L., Bandres, F., \& Gamella, C. (1994). Saliva electrolytes as a useful tool for anaerobic threshold determination. European journal of applied physiology and occupational physiology, 68(3), 214-218.

22. Mahler, P., \& Rostan, A. (1990). L’effort perçu: corrélation avec le seuil anaérobie et utilité dans un programme d'entraînement. Schweizerische Zeitschrift für Sportmedizin, 38(4), 187-191.

23. Matsumoto, T., Ito, K., \& Moritani, T. (1991). The relationship between anaerobic threshold and electromyographic fatigue threshold in college women. European journal of applied physiology and occupational physiology, 63(1), 1-5.

24. Morishita, S., Yamauchi, S., Fujisawa, C., \& Domen, K. (2014). Rating of perceived exertion for quantification of the intensity of resistance exercise. International Journal of Physical Medicine \& Rehabilitation, 1(172), 2.

25. Oliveira, L.d.S., Oliveira, S.F., Manchado-Gobatto, F.d.B., \& Costa, M.d.C. (2015). Salivary and blood lactate kinetics in response to maximal workload on cycle ergometer. Revista Brasileira de Cineantropometria \& Desempenho Humano, 17(5), 565-574.

26. Pinto, S.S., Brasil, R.M., Alberton, C.L., Ferreira, H.K., Bagatini, N.C., Calatayud, J., \& Colado, J.C. (2016). Noninvasive Determination of Anaerobic Threshold Based on the Heart Rate Deflection Point in Water Cycling. The Journal of Strength \& Conditioning Research, 30(2), 518-524.

27. Pokan, R., Hofmann, P., Preidler, K., Leitner, H., Dusleag, J., Eber, B., . . Klein, W. (1993). Correlation between inflection of heart rate/work performance curve and myocardial function in exhausting cycle ergometer exercise. European journal of applied physiology and occupational physiology, 67(5), 385-388.

28. Segura, R., Javierre, C., Ventura, J., Lizarraga, M., Campos, B., \& Garrido, E. (1996). A new approach to the assessment of anaerobic metabolism: measurement of lactate in saliva. British Journal of Sports Medicine, 30(4), 305-309.

29. Sentija, D., Vucetic, V., \& Markovic, G. (2007). Validity of the modified Conconi running test. International journal of sports medicine, 28(12), 1006-1011.

30. Svedahl, K., \& MacIntosh, B.R. (2003). Anaerobic threshold: the concept and methods of measurement. Canadian Journal of Applied Physiology, 28(2), 299-323.

31. Taylor, A., \& Bronks, R. (1994). Electromyographic correlates of the transition from aerobic to anaerobic metabolism in treadmill running. European journal of applied physiology and occupational physiology, 69(6), 508-515.

32. Tékus, É., Kaj, M., Szabó, E., Szénási, N., Kerepesi, I., Figler, M., ... Wilhelm, M. (2012). Comparison of blood and saliva lactate level after maximum intensity exercise. Acta Biologica Hungarica, 63(Supplement 1), 89-98.

33. Tyka, A., Pałka, T., Tyka, A., Cisoń, T., \& Szyguła, Z. (2009). The influence of ambient temperature on power at anaerobic threshold determined based on blood lactate concentration and myoelectric signals. International journal of occupational medicine and environmental health, 22(1), 1-6.

34. Forti, M., Zamunér, A.R., Kunz, V.C., Salviati, M.R., Nery, T.A.G., \& Silva, E.d. (2014). Ratings of perceived exertion at anaerobic threshold in patients with coronary artery disease. Fisioterapia e Pesquisa, 21(2), 113-119.

35. Helal, J., Guezennec, C., \& Goubel, F. (1987). The aerobic-anaerobic transition: re-examination of the threshold concept including an electromyographic approach. European journal of applied physiology and occupational physiology, 56(6), 643-649.

36. Carvalho, V.O., Bocchi, E.A., \& Guimarães, G.V. (2009). The Borg Scale as an Important Tool of Self-Monitoring and Self-Regulation of Exercise 
Prescription in Heart Failure Patients During Hydrotherapy A Randomized Blinded Controlled Trial. Circulation Journal, 73(10), 1871-1876.

37. Claver, J.B., Mirón, M.V., \& Capitán-Vallvey, L. (2009). Disposable electrochemiluminescent biosensor for lactate determination in saliva. Analyst, 134(7), 1423-1432.
38. Conconi, F., Ferrari, M., Ziglio, P., Droghetti, P., Borsetto, C., Casoni, I., . . . Paolini, A. (1982). Determination of the anaerobic threshold by a noninvasive field test in running and other sport activities: Paper presented at the Current topics in sports medicine, World Congress, Vienna.

\title{
NICHT-SPIROGRAPHISCHE UND NICHT-INVASIVE METHODEN FÜR DIE EINSCHÄTZUNG DER ANAEROBEN SCHWELLE
}

\begin{abstract}
Zusammenfassung
In der Welt von Sportuntersuchungen gibt es verschiedene Wege für die Einschätzung der Körperverfassung - die Palette reicht von teuren labor-invasiven Methoden bis zu billigen, nicht-invasiven Methoden im Gelände. Tests, die auf nicht-invasiven Methoden gründen, haben eine gute Zuverlässigkeit und einen niedrigen Preis für die Anwendung von physiologischen Parametern wie zum Beispiel: Puls, Elektrolyte oder Laktat aus Speichel, wahrgenommene Anstrengung und Elektromiographie. Diese Parameter können für die Einschätzung der anaeroben Schwelle (AnT) angewendet werden, die für Prognosen von Sportleistungen, Umgestaltung von Trainings verwendet wird und Trainern und Sportlern helfen kann, wettbewerbsfähiger zu werden. Jeder dieser Parameter hat jedoch seine Eigentümlichkeiten und Kontroversen wegen unterschiedlicher Ergebnisse, die von Experten präsentiert werden. Diese Unterschiede können unter anderem durch Prüfungen der angewendeten Protokolle, durch die Musterebene der Sportler, die anfängliche Intensität oder die Anzahl der Qualitätsebenen der Sportler erklärt werden. Trotz allem haben sie auch weiterhin eine gute Wiederholbarkeit und Anwendung auf Prüfungen der Protokolle, die auf den Geländebedingungen gründen. Die angeführten Tests können in bedeutendem Maße angewendet werden, wobei die Korrelationsstufe mit originellen invasiven Tests und der Prozentsatz möglicher Fehler im Einschätzungsprozess beachtet werden müssen. Billigere und einfachere Tests (anstatt subjektiver Einschätzungen der Trainingsbelastung) ermöglichen eine präzisere Planung, änderen den Umfang und die Intensität des Trainings für den Trainer und den Sportler und fordern somit eine niederigere Bildungsebene und weniger finanzielle Mittel. Der Komfort der Sportler und mögliche häufigere Untersuchungen im Laufe von nicht-invasiven Tests können als Vorteil während des Evaluierungsprozesses von Trainings hervorgehoben werden.
\end{abstract}

Schlüsselwörter: PULS / SPEICHEL / WAHRNEHMUNG DER ANSTRENGUNG / ELEKTROMIOGRAPHIE / LAKTAT IM BLUT / ERGOMETRIE

Примљен: 24.04.2017.

Прихваћен: 10.05.2017. 